\title{
MANNIA LEVIGATA (MARCHANTIOPHYTA: AYTONIACEAE) FIRST RECORD OUTSIDE OF JAPAN IN THE RUSSIAN FAR EAST
}

\author{
Eugene A. BOROVICHEV \& VADIM A. BAKALIN
}

\begin{abstract}
Mannia levigata Shimizu \& S. Hatt. is reported for Russia based on a recent collection from Primorsky Territory. This species was known from Japan and was treated as a Japanese endemic. Here it is described, illustrated and differentiated from other species of Mannia Opiz.
\end{abstract}

Key words: Hepatics, Aytoniaceae, distribution, phytogeography, Russian Far East

Eugene A. Borovichev, N. A. Avrorin Polar-Alpine Botanical Garden, Institute of Kola Science Centre of the Russian Academy of Sciences, Apatity, Murmansk Province, 184209 \& Institute of Industrial Ecology Problems of the North, Kola Science Center of the Russian Academy of Sciences, Apatity, 184209, Russia; e-mail: borovichyok@mail.ru

Vadim A. Bakalin, Botanical Garden-Institute, Vladivostok, 690024 \& Institute of Biology and Soil Science, Vladivostok, 690022, Russia; e-mail:v_bak@list.ru

In the course of a taxonomical survey of Russian Far East Cleveaceae and Aytoniaceae, the first author had the opportunity to find specimens that were misidentified as Athalamia nana (Shimizu \& S. Hatt.) S. Hatt. but represent Mannia Opiz. Further studies showed its identity with Mannia levigata Shimizu \& S. Hatt. described by Shimizu and Hattori (1953) from Japan and before treated as a Japanese endemic.

Mannia is not a large genus, numbering 16 species worldwide and distributed primarily in areas with Mediterranean climate (Frey 2009). In this respect the south of the Russian Far East and the Korean Peninsula, which have rather a monsoon climate, or Japan with oceanic climate dominating, differ considerably from the presumed ecological requirements of Mannia. Data at hand show four species recorded for the Russian Far East: M. androgyna (L.) A. Evans (Borovichev \& Bakalin 2013), M. fragrans (Balb.) Frye \& L. Clark, M. pilosa (Hornem.) Frye \& L. Clark, M. sibirica (Müll. Frib.) Frye \& L. Clark, and M. triandra (Scop.) Grolle (Konstantinova et al. 2009). Among these, the distribution of $M$. triandra seems restricted to the northernmost part of the area and the others tend to have a more southern distribution. Three species are recorded for Japan: M. fragrans, $M$. triandra and M. levigata (Yamada \& Iwatsuki 2006). Four are noted for China - M. fragrans, M. triandra, M. sibirica and M. subpilosa (Horik.) Horik (Piippo 1990). No species were recorded from the Korean Peninsula but we believe they should be present there too.

Mannia levigata probably belongs to the temperate flora element. The species was described from Kaminakao in the Chichibu Mts where it grows in 'rock crevices in exposed place' (Shimizu \& Hattori 1953: 51). It was regarded as rather distant from other Japanese species of Mannia due to '(1) smooth, pale green and not aromatic thallus, (2) stalk of female receptacle with a few slender scales at the base and quite naked above, (3) densely punctate spores with low ridges forming loose and very irregular areolae, and the same punctate elaters' (1.c.: 51). Later Inoue and Shimizu (1968) reviewed the genus Mannia in Japan and described some discrepancies between the original description of M. levigata and Inoue's observations of fresh material from the type locality. The cited work also stressed the distribution of the species within the type locality only, where it is rather abundant. Up to the present it has been 
regarded as a strict Japanese endemic and its record in the Russian Far East is unexpected. Below we describe the species based on the material from the Russian Far East, except for bracketed data on the carpocephalum and sporophyte, which come from Shimizu and Hattori (1953) and Inoue and Shimizu (1968).

Mannia levigata Shimizu \& S. Hatt., J. Hattori Bot. Lab. 10: 49. 1953.

Thalli (8-)10-18 $\mathrm{mm}$ long and 2-4(-5) $\mathrm{mm}$ wide, forming small mats or growing a single plants over mosses, thin, very delicate, almost plane; branching dichotomous terminal, often from beneath female receptacle; thallus margins slightly recurved when dry and almost plane when wet, purple to violet; segments sublingulate to obcordate; upper surface smooth, pale- to pure green, not areolate. Dorsal epidermis delicate, composed of moderately thick-walled almost isodiametric cells, 14-22 × 16-25 $\mu \mathrm{m}$, with small triangle trigones; oil cells very rare, with one oil body per cell; pore simple, small, slightly elevated above epidermis; surrounded by $2-3$ concentric rows of (4-)6-8 cells, 6-12 × 10-20(-28) $\mu \mathrm{m}$. Thallus thin, ca 530-700 $\mu \mathrm{m}$ high in the middle, slightly canaliculate. Ventral tissue developed in middle part of thallus and almost absent in wings, $250-360(-420) \mu \mathrm{m}$ thick in middle, occupying $1 / 2-2 / 3$ of thallus thickness, with scattered tawny oil bodies. Aerenchyma compact, 150-270 $\mu \mathrm{m}$ of thallus thickness, occupying $1 / 2-1 / 3$ of thallus thickness, 2-3(-4)-layered in the thallus middle; air-chambers small, subquadratic to rounded, 45-60(-90) $\mu \mathrm{m}$, with chlorophyllose filaments. Lower surface green, hidden by glossy rose to purple ventral scales. Rhizoids smooth or pegged, hyaline, forming dense cluster along midrib region. Ventral scales imbricate, deep purple red to violet, 70-90(-150) $\mu \mathrm{m}$ wide and 250-430 $\mu \mathrm{m}$ long, with scattered oil bodies; appendage one per ventral scale, narrowly triangular, rarely projecting (only near thallus apex). Autoicous. Androecia on branches separate from female ones, in 2-3 irregular series, conical to elliptical, reddish, without scales, [small, sessile]. Gynoecia arising in apical notch of leading branches, $f e$ male receptacle stalk with a single rhizoid furrow, [3.5 10 14 mm long], with few small filiform reddish scales at base [and apex, on the intermediate portion of the stalks there are often small, filiform scales]. [Carpocephalum grayish green, 2.0-3.5 $\mathrm{mm}$ in diameter, roof of carpocephalum reticulate to slightly papillose, convex, rounded in dorsal view, with 2-5 membranous perichaethia. Sporophyte 1-5 per receptacle; capsule spherical, deep red-brown, opening by caducous apical lid. Spores deep brown, 56-72 $\mu \mathrm{m}$ in diameter, distal face very weakly verrucose or sometimes virtually smooth $^{1}$, with irregular areolations. Elaters brown, very weakly verrucose, $160-200-240 \mu \mathrm{m}$ long and (11-)12-13 $\mu \mathrm{m}$ wide, 2-3 spiral].

SPECIMENS EXAMINED: RUSSIA, PRIMORSKY TERRITORY, Muravjov-Amursky Peninsula, Okeansky Range, left side of Bogataya River $\left(43^{\circ} 14^{\prime} 31,8^{\prime \prime} \mathrm{N}\right.$, $\left.132^{\circ} 05^{\prime} 25,8^{\prime \prime} \mathrm{E}\right), 44 \mathrm{~m}$ a.s.l., 14 June 2008, V. A. Bakalin \#P-5-1-08 (VBGI).

The species was described as growing in 'rock crevices in exposed places' (Shimizu \& Hattori, 1953: 51) at $750 \mathrm{~m}$ a.s.l. Our data differ somewhat from that. The specimen was collected on fine earth in a cliff crevice, rather shaded, in the flood valley of a stream in broadleaved forest with herb and shrub cover at $44 \mathrm{~m}$ a.s.l. If the altitude difference may be explained by the more northern location, the habitat data enlarges the species ecology. It may be one of the temperate relicts in the south of the Russian Far East, along with species of Trocholejeunea, Plicanthus and Hattorianthus (also recorded near the M. levigata locality), which is sparsely distributed in the treated area and contrasts with the surrounding vascular plant biota.

The authors of the original description (Shimizu \& Hattori 1953) treated the species as rather distant from all then-recognized species of the genus. Later Inoue and Shimizu (1968: 408) suggested $M$. levigata as a taxon 'fairly closely related to Mannia pilosa-sibirica complex'. In our estimation those two species are very different from each

\footnotetext{
1 As was stressed by Inoue and Shimizu (1968), never densely verrucose as illustrated by Shimizu and Hattori (1953).
} 

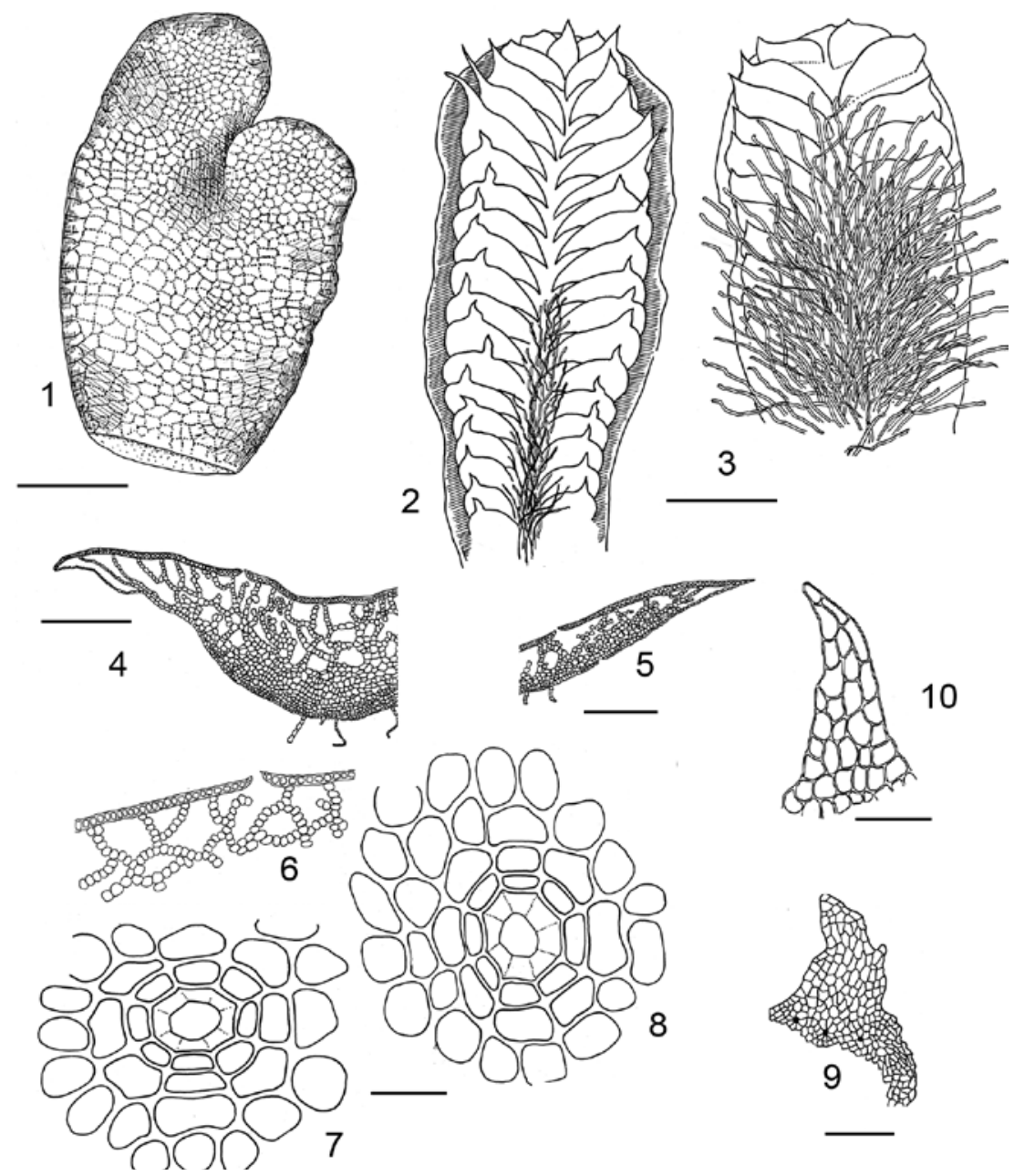

Fig. 1. Mannia levigata Shimizu \& S. Hatt. 1 - thallus, dorsal view; 2 \& 3 - thallus, ventral view; 4-6 - transverse section of thallus; 7-8 - air pore from dorsal epidermis of thallus; 9 - ventral scales of thallus; 10 - appendage of ventral scales of thallus. Scale bars: $2.5 \mathrm{~mm}$ for $1-3 ; 600 \mu \mathrm{m}$ for $5 ; 20 \mu \mathrm{m}$ for $7-8 ; 400 \mu \mathrm{m}$ for $4 ; 1 \mathrm{~mm}$ for $6 ; 300 \mu \mathrm{m}$ for $4-5 ; 150 \mu \mathrm{m}$ for 9 ; $100 \mu \mathrm{m}$ for 10 .

other and do not form a morphological cluster. $M$. levigata seems to occupy an isolated position within the genus due to having (i) a thin thallus; (ii) the upper surface of the thallus very delicate, pale to deep green; ( $\mathrm{iii}$ ) thallus margins purple to violet, almost plane when wet; $(i v)$ ventral scales rare, projecting only at the apical region of the thallus; and $(v)$ one appendage per ventral scale having scattered oil cells.

Despite its isolated morphological position, Mannia levigata can be mistaken for other
Mannia species and those of the genera Clevea and Peltolepis (Cleveaceae). M. levigata differs from $M$. fragrans and M. androgyna in having ( $i$ ) a delicate, pale to deep green thallus; (ii) a single appendage of ventral scales, and (iii) ventral scales often not projecting beyond the thallus margins. The species may also be confused with Mannia triandra. The latter differs from it in having $(i)$ discoid androecia; (ii) 'empty' air-chambers of the thalli, without loose chlorophyllose filaments, (iii) a lacunose upper surface of thallus, and (iv) an 


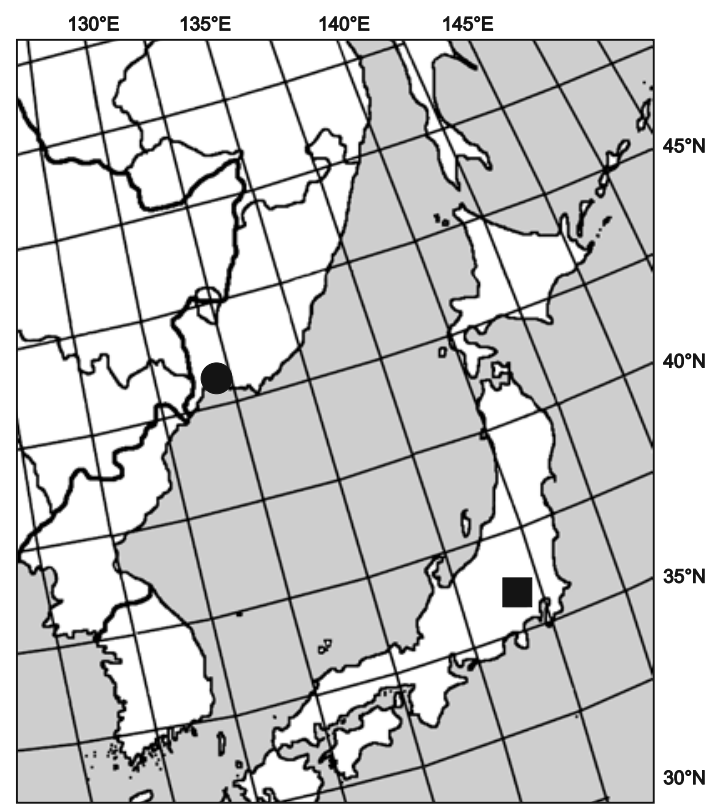

Fig. 2. Distribution of Mannia levigata Shimizu \& S. Hatt. in the Russian Far East (circle) and Japan (square).

arctic to alpine distribution. Mannia differs from Clevea in the terminal position of the gynoecia; the gynoecia of Clevea are always dorsal. Mannia levigata differs from Peltolepis in the shape of androecia, which in M. levigata androecia are conical to elliptic in 2-3 irregular series whereas in Peltolepis they form a compact disc surrounded by small red scales, and by the single rhizoidal furrow of the female receptacle vs. two rhizoidal furrows in Peltolepis.

Our specimen falls within the variability of the species except for the number of ventral scale appendages. Typically, as described by Shimizu and Hattori (1953), it has 1-2 appendages, but in our specimen we found only 1-appendaged ventral scales. This discrepancy probably can be explained by wider morphological variability then suggested by the cited authors.

ACKNOWLEDGMENTS. We thank Matvei A. Bakalin for kindly preparing the figure, and the anonymous reviewer for useful remarks on the manuscript. The work was supported in part by the Russian Foundation for Basic Research (grants 12-04-91150 ГФЕН, 12-04-01476, 13-04-00775, 13-04-90742).

\section{REFERENCES}

BorovicheV E. A. \& BAKALIN V. A. 2013. New national and regional bryophyte records. Mannia androgyna (L.) A. Evans (Southern Far East, Russia). Journal of Bryology (in press).

FREY W. (ed.) 2009. Syllabus of plant families. Adolf Engler's Syllabus der Pflanzenfamilien. 13th edition. Part 3. Bryophytes and seedless vascular plants. Gebr. Borntraeger Verlagsbuchhandlung, Stuttgart.

INOUE H. \& SHIMIZU D. 1968. Notes on the genus Mannia Corda in Japan. Bulletin of the National Science Museum, Tokyo. 11(4): 405-410.

Konstantinova N. A., Bakalin V. A., Andrejeva E. N., Bezgodov A. G., Borovichev E. A., Dulin M. V. \& MAMONTOV YU. S. 2009. Check-list of liverworts (Marchantiophyta) of Russia. Arctoa 18: 1-63.

SHIMIZU D. \& HATTORI S. 1953. Marchantiales of Japan, II. J. Hattori Bot. Lab. 10: 49-55.

PIIPPO S. 1990. Annotated catalogue of Chinese Hepaticae and Anthocerotae. J. Hattori Bot. Lab. 68: 1-192.

YAMADA K. \& IWATSUKI Z. 2006. Catalog of the hepatics of Japan. J. Hattori Bot. Lab. 99: 1-106. 